\title{
Influence of crown-to-implant ratio of short vs long implants on implant stability and marginal bone loss in the mandibular single molar implant
}

\author{
Yeon-Wha Baek1, Bongju Kim², Myung-Joo Kim¹, Ho-Beom Kwon', Young-Jun Lim* \\ 'Department of Prosthodontics and Dental Research Institute, School of Dentistry, Seoul National University, Seoul, Republic of Korea \\ ${ }^{2}$ Dental Life Science Research Institute and Clinical Translational Research Center for Dental Science, Seoul National University \\ Dental Hospital, Seoul, Republic of Korea
}

Purpose: The purpose of this randomized clinical trial is to determine whether implant length and the crown-to-implant (C/I) ratio influence implant stability and peri-implant marginal bone loss (MBL). Materials and Methods: 46 patients with single tooth missing in the posterior molar region of the mandible were included in this study. 19 implants (CMI IS-III active ${ }^{\circledR}$ long implant) of $5.0 \mathrm{~mm}$ diameter and $10 \mathrm{~mm}$ length were installed for the control group, while 27 implants (CMI IS-III active ${ }^{\circledR}$ short implant) of $5.5 \mathrm{~mm}$ diameter and $6.6,7.3$ or $8.5 \mathrm{~mm}$ length were placed for the experimental group. Each implant was inserted and immediately loaded using the digitally pre-fabricated surgical template and provisional restoration. The CAD-CAM monolithic zirconia crown was fabricated at 3 months after the surgery as a definitive restoration. The ISQ value and the MBL was measured at 48 weeks after the surgery. The correlation between the C/I ratio, MBL, and secondary implant stability was analyzed. Results: Successful results in terms of ISQ and MBL were achieved with both groups. There was no significant difference between the groups in terms of ISQ values and MBL at 48 weeks after the surgery $(P>0.05)$. No significant correlation was found between the $C / I$ ratio and secondary stability as well as the $C / I$ ratio and the MBL $(P>0.05)$. Conclusion: The influence of $C / I$ ratio in both groups was not shown on the stability nor the marginal bone loss in implants supporting single crown of the mandible. Short implant could be a preferable alternative option in the reduced bone height mandible under the limited condition despite its higher C/I ratio. (J Dent Rehabil Appl Sci 2018;34(4):280-9)

Key words: dental implants; short dental implants; immediate loading; primary stability; marginal bone loss; crown to implant ratio

\begin{abstract}
서론
수 십년 간의 성공적인 임상 결과와 끊임없는 개선에 의해 임플란트는 상실치 수복 시 우선시되고 보편적인 치 료 방법으로 자리잡았다. 빈번한 결손부인 구치부의 경 우 치조골 흡수 및 상악동, 하치조 신경 등의 해부학적 구조물로 골높이가 부족한 경우가 흔하여 임플란트 식립 을 위해 상악동거상술, 골유도재생술, 하치조신경이동술 등 가용한 골높이 증가를 위한 별도의 수술이 필요하다. 이 같은 수술은 수십 년 간의 임상 경험을 통해 신뢰할

*Correspondence to: Young-Jun Lim

Professor, Department of Prosthodontics and Dental Research Institute, School of Dentistry, Seoul National University, 101, Daehak-ro, Jongno-gu, Seoul, 03080, Republic of Korea

Tel: +82-2-2072-2940, Fax: +82-2-2072-3860, E-mail: limdds@snu.ac.kr Received: September 7, 2018/Last Revision: September 28, 2018/Accepted: October 10, 2018
\end{abstract}

만한 술식으로 자리잡았으나 ${ }^{1}$ 수술에 대한 부담감, 술후 불편감 및 치료 시간의 증가 등의 단점 때문에 대안으로 짧은 길이의 임플란트를 상용화하기 위한 많은 연구들 이 있었다. 초기의 많은 논문들은 짧은 길이의 임플란트 가 표준 길이에 비해 성공률이 낮고 임플란트 길이는 성 공률과 관련이 있다고 보고하였다. ${ }^{2.4}$ 그러나 임플란트의 표면, 디자인, 수술방식 등에 대한 꼲임없는 연구 및 개선 의 결과로 최근에는 임플란트 길이에 따른 성공률 차이 는 없었다는 보고가 증가하고 있다. ${ }^{5.7}$ 일부 논문에서는 골높이가 부족한 경우, 골이식술을 동반하여 길이가 긴

CopyrightC 2018 The Korean Academy of Stomatognathic Function and Occlusion. (c) It is identical to Creative Commons Non-Commercial License. 
임플란트를 식립하는 것보다 골이식술 없이 길이가 짧은 임플란트를 심는 것을 보다 더 효율적인 술식으로 제안 하기도 하였다. ${ }^{8-10}$

그러나 이러한 긍정적인 보고에도 불구하고 대체적으 로 임상가들은 짧은 길이의 임플란트 사용에 대한 의구 심이 있는데 이에 대한 이유 중 하나로 역학적으로 불리 한 치관-임플란트 비율(crown-to-implant $(\mathrm{C} / \mathrm{I})$ ratio)을 들 수 있다. 전통적으로 자연치의 예후 평가 시 치관-치근 비율(crown-to-root (C/R) ratio)을 중요한 요인으로 고 려하였다. 많은 연구들에서 치관-치근 비율이 증가할 경 우 1 종 지렛대 작용에 의해 교합력에 보다 취약하게 되며 고정성 보철물을 수복하기 위해서는 지대치가 최소 $1: 2$ 의 치관-치근 비율을 갖는 것이 이상적이라고 보고하였 다. ${ }^{11-14}$ 이러한 자연치에서의 원칙을 그대로 임플란트에 도 적용하여 적절한 치관-임플란트 비율을 찾아내려는 많은 연구가 있었으나 각 연구마다 다양한 결과가 보고 된 바 치관-임플란트 비율과 임플란트의 예후 간의 관계 는 아직 확립되지 않은 상태이다.

본 논문에서는 하악 단일 구치부에서 다양한 길이의 임플란트를 통해 임플란트 길이에 따른 치관-임플란트 비율이 임플란트의 안정성과 변연골 소실(marginal bone loss; MBL)에 영향을 주는지에 대해 알아보고자 하였다.

\section{연구 재료 및 방법}

\section{1. 연구 대상}

본 임상시험을 위해 하악 제 1 대구치 혹은 제 2 대구치 단일치아 발치 후 최소 3 개월이상 경과한 지원자들 중 선 정기준과 제외기준을 적용하여 52명을 선별하였다. 흡 연, 이갈이, 임산부 등 임플란트에 부적절한 자나 술 전 $\mathrm{CT}$ 상 나타나는 골밀도 D4 환자는 제외하였다. 본 연구 는 헬싱키 선언(Helsinki Declaration, 2000)에 따라서 진 행되었으며, 이 연구 계획은 서울대학교 치과병원 Institutional Review Board (IRB No. CDE16004)의 승인을 받았다.

\section{2. 연구 방법}

1) 술 전 진단 및 준비

모든 연구대상자는 임플란트 수술 및 보철 수복 계 획을 위해 술 전 진단 및 준비과정을 진행하였다. 먼저,
진단을 위해 파노라마와 CBCT $\left(\mathrm{CS} 9300^{\circledR}\right.$, Carestream Health, Rochester, NY)를 촬영하고 구강스캐너를 이 용하여 디지털 인상을 채득하였다. CT영상과 디지털 인 상 데이터를 기반으로 소프트웨어 Implant $\operatorname{Studio}^{\mathrm{TM}}$ (3 Shape, Copenhagen, Denmark) 상에서 해부학적 구조와 악간 관계를 고려하여 임플란트 식립 및 보철 수복을 계 획하였다. 이 계획에 따라 수술가이드와 맞춤형 티타늄 지대주 및 임시보철물을 제작하였다.

2) 임플란트 식립 수술

임플란트 고정체는 시판되고 있는 CMI IS-III active ${ }^{\circledR}$ (Neobiotech, Seoul, Korea)를 사용하였으며 대조군에는 19 개의 지름 $5 \mathrm{~mm} \times$ 길이 $10 \mathrm{~mm}$ 의 고정체를, 실험군 에는 지름 $5.5 \mathrm{~mm} \times$ 길이 $6.6 \mathrm{~mm}$ 8개, $7.3 \mathrm{~mm}$ 9개, 8.5 $\mathrm{mm} 10$ 개, 총 27 개의 고정체를 무작위로 배정하여 식립 하였다. 2 명의 경험이 풍부한 치주과 의사가 디지털 수술 가이드를 사용하여 무절개로 Neobiotech 사의 즉시부 하 식립방법대로 시행하였다. 식립 토크가 $35-45 \mathrm{Ncm}$ 가 되도록 조정하였고 Osstell ${ }^{\mathrm{TM}}$ Mentor $^{\circledR}$ (Integration Diagnostics AB, Göteborg, Sweden)를 이용하여 ISQ (Implant Stability Quotient) 값을 측정하였다. 식립 토크 가 $35-45 \mathrm{Ncm}$ 범위를 벗어나거나 ISQ 값이 65 미만인 경우 실험 대상에서 제외하였다.

\section{3) 보철물 장착}

임플란트 식립 1주 후 미리 제작해 놓은 임시치아를 연 결하여 즉시하중부하를 시행하였다. 임플란트 식립 12 주 후에 지르코니아 크라운을 CAD-CAM 방식으로 제 작하여 최종 수복하였다.

\section{4) 평가}

(1) 안정도(stability) 측정

안정도 검사는 임플란트 식립 직후와 임시보철물 장착 시(식립 후 1주), 식립 후 $3,4,8$ 주, 최종보철물 장착 시 (식립 후 12주), 임플란트 식립 후 24, 36, 48주 후 Osstell Mentor $^{\mathrm{TM}}$ 를 이용하여 ISQ 값을 측정하였고, 측정 시 마 다 총 4회 측정 후(근심, 원심, 협측, 설측) 평균값을 계산 하였다.

(2) 임플란트 변연골 소실량 측정

임플란트 식립 직후, 48 주 후에 표준치근단방사선 사 진을 촬영하여 임플란트 변연골 소실량을 평가하였다. 
방사선 사진 상에서 임플란트 고정체 pitch간의 거리를 측정(b)하고 실제의 pitch간 거리인 $0.9 \mathrm{~mm}$ 와의 비를 이 용하여 방사선 사진상의 거리와 실제 거리와의 환산률을 계산하였다. 식립 직후와 48주 후 촬영한 방사선 사진에 서 각각 고정체 플랫폼 최상단으로부터 치조정간의 거리 (a)를 방사선 사진상에서 측정 후 앞에서 계산한 환산률 을 반영하여 실제 플랫폼으로부터 치조정간의 거리(x)로 환산하였다. 이렇게 산출된 48주의 플랫폼에서 치조정간 의 거리(48주 후의 $\mathrm{x}$ )에서 식립 직후의 거리(식립 직후의 $\mathrm{x}$ 를 차감하여 변연골의 변화량을 구하였다(Fig. 1). 근 심, 원심에서 각각 측정하고 평균치를 계산하였다.

\section{(3) 치관-임플란트 비율 측정}

표준 치근단 방사선 사진에서 치관과 임플란트의 길이 를 측정하였다. 치관의 길이는 임플란트 플랫폼에서 수 복물의 가장 높은 곳까지의 길이를, 임플란트의 길이는 임플란트 플랫폼에서 치근단까지의 길이를 플랫폼에 수 직으로 측정하였다. 치관 길이를 임플란트 길이로 나누 어 치관-임플란트 비율을 계산하였다(Fig. 2). 실험군, 대 조군 별로 각각 평균 치관-임플란트 비율을 계산하였다.

\section{(4) 상관관계분석}

두 군의 임플란트 치관-임플란트 비율, 식립 후 48 주 의 ISQ 값, 그리고 식립 48 주 후의 변연골 소실량을 사용 하여 임플란트 치관-임플란트 비율과 안정도의 상관관계 및 임플란트 치관-임플란트 비율과 변연골 소실량 간의 상관관계를 각각 분석하였다.

\section{(5) 통계적 분석}

대조군과 실험군에서의 치관-임플란트 비율, ISQ, 변 연골 소실량 측정치에 대해 정규성 검정(Shapiro-Wilk)을 수행하였다. 정규성 검정을 통과한 치관-임플란트 비율 및 ISQ에 대해서는 독립 표본 $\mathrm{t}$ 검정을 사용하였고, 통과 하지 못한 변연골 소실량에 대해서는 Mann-Whitney 검 정을 사용하여 비교 분석하였다. 치관-임플란트 비율이 임플란트 안정성 및 변연골 소실량에 미치는 영향을 알 아보기 위하여 선형 상관관계 분석을 수행하였다. 모든 변수는 평균과 표준편차로 나타내었으며, $P<0.05$ 를 통 계학적 유의성 있는 것으로 설정하였다(Sigma Plot 12.0, Systat Software Inc. San Jose, USA).

\section{결과}

본 연구 결과 분석에 포함된 환자 수는 총 46 명(평균 연령: $54.54 \pm 11.55$ 세/범위: 27 - 75세/남: 34명, 여: 12 명)으로 처음 선별한 52 명 중 환자의 변심 또는 본 연구 프로토콜 기준에 의해 6 명의 환자가 중도 탈락되었다. 실 험군과 대조군 간 성별, 나이, 골밀도에 있어 통계적 유 의성 있는 차이는 없었다. 최종 분석에 포함된 개수는 총 46 개로 대조군 $10 \mathrm{~mm}$ 19개와 실험군 $6.6 \mathrm{~mm} 8$ 개, 7.3 $\mathrm{mm}$ 9개, $8.5 \mathrm{~mm} 10$ 개였다.

치관-임플란트 비율은 대조군 평균 $1.00 \pm 0.12$, 실험 군 평균은 $1.36 \pm 0.29$ 으로 나타났으며 두 그룹간 값의 차이는 통계적으로 유의성이 있었다 $(P<0.001)$ (Table 1). 그룹별로 치관-임플란트 비율 분포는 Fig. 3 과 같다.

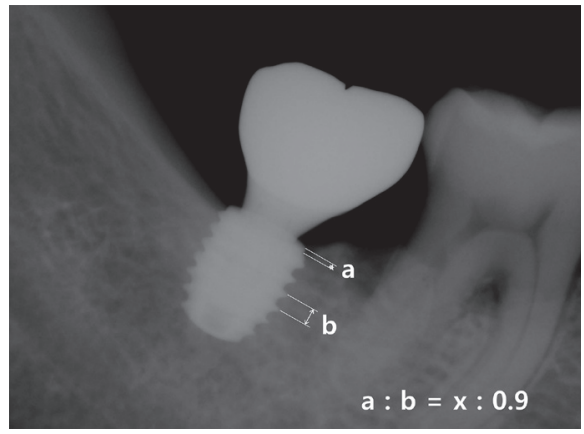

Fig. 1. Measurement of marginal bone loss (MBL) on periapical radiograph ( $x$ : distance between platform and periimplant bone crest).
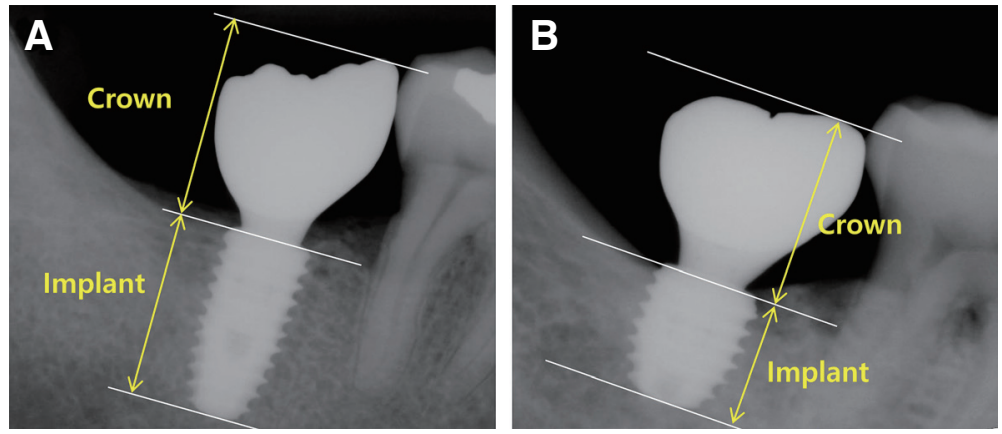

Fig. 2. Measurement of $C / I$ ratio on periapical radiograph, $(A)$ Control group: CMI IS-III active ${ }^{\circledR}$ diameter $5 \mathrm{~mm} \times$ length $10 \mathrm{~mm}$, (B) Experimental group: CMI IS-III active ${ }^{\circledR}$ diameter $5.5 \mathrm{~mm} \times$ length $6.6 \mathrm{~mm}$. 
Table 1. Crown- to- implant ratio

\begin{tabular}{lccccc}
\hline & \multicolumn{2}{c}{ Control Neobiotech } & \multicolumn{2}{c}{$\begin{array}{c}\text { Experimental Neobiotech } \\
\text { CMI IS-III active }{ }^{\circledR} \text { long Implant }\end{array}$} & CMIS-III active ${ }^{\circledR}$ short Implant \\
& $\mathrm{N}$ & C/I ratio & C/I ratio & $P$ value* \\
\hline Mean \pm SD & 19 & $1.00 \pm 0.12$ & 27 & $1.36 \pm 0.29$ & $P<0.001$ \\
Median & 19 & 1.03 & 27 & 1.37 \\
Max & 19 & 1.19 & 27 & 1.89 \\
Min & 19 & 0.71 & 27 & 0.64 \\
\hline
\end{tabular}

*The P-values were calculated using the t-test.

Normality test was passed (Shapiro-Wilk, $P=0.793)$.

$\mathrm{SD}$, standard deviation.
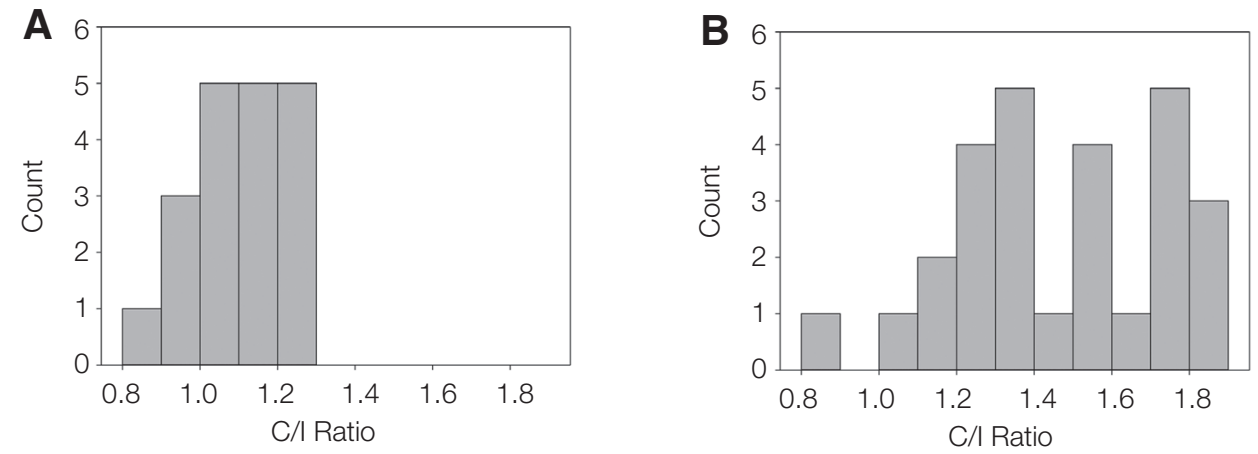

Fig. 3. Frequency of crown- to- implant ratio (A) long implant group, (B) short implant group.

Table 2. Comparison of ISQ value at 48 weeks after surgery between the long and short implants

\begin{tabular}{lccccc}
\hline & \multicolumn{2}{c}{ Control Neobiotech } & \multicolumn{2}{c}{$\begin{array}{c}\text { Experimental Neobiotech } \\
\text { CMI IS-III active }\end{array}$} \\
& $\mathrm{N}$ & Mean \pm SD & $\mathrm{N}$ & Mean \pm SD & $P$ value* \\
\hline ISQ at surgery & 19 & $81.53 \pm 6.26$ & 27 & $78.69 \pm 5.08$ & 0.105 \\
ISQ at 48 weeks after surgery & 19 & $90.76 \pm 2.09$ & 27 & $91.51 \pm 1.79$ & 0.207 \\
\hline
\end{tabular}

The $P$ values for insertion torque and ISQ were calculated by the t-test.

ISQ, implant stability quotient; SD, standard deviation.

Table 3. Comparison of marginal bone loss at 48 weeks after surgery between the long and short implants

\begin{tabular}{|c|c|c|c|c|c|c|}
\hline \multirow[b]{2}{*}{ Duration } & \multirow[b]{2}{*}{ Area } & \multicolumn{2}{|c|}{$\begin{array}{l}\text { Control Neobiotech } \\
\text { CMI IS-III active }{ }^{\circledR} \text { long Implant }\end{array}$} & \multicolumn{2}{|c|}{$\begin{array}{l}\text { Experimental Neobiotech } \\
\text { CMI IS-III active }^{\circledR} \text { short Implant }\end{array}$} & \multirow[b]{2}{*}{$P$ value ${ }^{*}$} \\
\hline & & $\mathrm{N}$ & Mean \pm SD & $\mathrm{N}$ & Mean \pm SD & \\
\hline \multirow[t]{3}{*}{ 48-week follow up } & Mesial & 19 & $-0.15 \pm 0.94$ & 27 & $-0.13 \pm 0.82$ & 0.719 \\
\hline & Distal & & $0.27 \pm 0.80$ & & $0.23 \pm 0.92$ & 0.573 \\
\hline & Avg & & $0.06 \pm 0.82$ & & $0.05 \pm 0.77$ & 0.655 \\
\hline
\end{tabular}

*The $P$ values were calculated using the Mann-Whitney test.

Normality test was failed (Shapiro-Wilk, $P<0.05$ ).

Area, the radiographic measurement area for calculation of marginal bone loss; Avg, the average value of mesial and distal bone loss; SD, standard deviation.

술 후 48 주에 측정한 ISQ 값은 대조군, 실험군 모두에 서 수술 시보다 증가하여 만족할만한 높은 수치를 나타 냈으며 대조군과 실험군간 유의성 있는 차이는 없었다 $(P$ $>0.05)$ (Table 2). 술 후 48 주의 변연골 소실량의 평균값
은 대조군 $0.06 \pm 0.82 \mathrm{~mm}$, 실험군 $0.05 \pm 0.77 \mathrm{~mm}$ 으로 그룹간에는 유의한 차이가 없었다 $(P>0.05)$ (Table 3).

치관-임플란트 비율과 ISQ 값의 상관관계 분석결과 통계적 유의성이 없었으며 치관-임플란트 비율과 변연골 
Table 4. Correlations between C/I ratio : ISQ value and $\mathrm{C} / \mathrm{I}$ ratio : $\mathrm{MBL}$

\begin{tabular}{lcc}
\hline Correlation & C/I ratio : ISQ value & C/I ratio : MBL \\
\hline $\mathrm{r}$ & 0.096 & 0.066 \\
$P$ value & 0.527 & 0.757 \\
Significance & $\mathrm{NO}$ & $\mathrm{NO}$ \\
\hline
\end{tabular}

Correlation coefficients were calculated using linear regression.
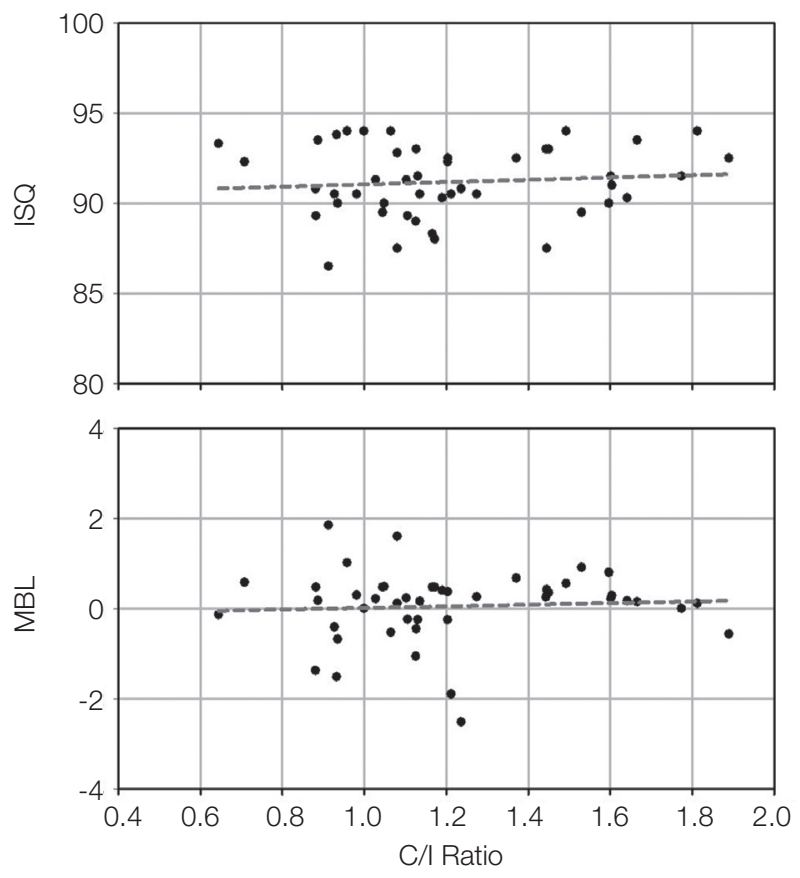

Fig. 4. Correlation of $\mathrm{ISQ}$ and $\mathrm{C} / \mathrm{I}$ ratio, $\mathrm{MBL}$ and $\mathrm{C} / \mathrm{I}$ ratio.

소실량 간에도 유의미한 상관관계가 없는 것으로 나타났 다(Table 4, Fig. 4).

\section{고찰}

본 연구는 환자 편의의 간편한 술식을 추구하는 추세 에 맞추어 길이가 짧은 임플란트를 골이식 없이 식립하 고 즉시하중을 부하하는 실험을 디자인하였다. 또한 진 단, 수술, 보철에 이르기까지 모두 디지털 workflow에 의 해 행함으로써 한번의 내원으로 진단 및 수술, 보철 계획 에 필요한 모든 자료를 채득하고, 수술가이드를 이용하 여 비절개수술을 행하였으며 미리 만들어둔 임시 보철을
즉시 하중함으로써 환자의 내원횟수, 시술시간 및 술후 불편감을 감소시키고 즉시 수복을 시행하여 보다 환자 편의를 고려하였다. 본 실험의 프로토콜 기준을 모두 충 족시키는 환자들이 최종 분석대상에 포함되었으며 모든 임플란트(총 46개)는 48주의 관찰기간 동안 성공기준을 충족하였다.

48주째에 측정한 ISQ 값은 대조군, 실험군 모두에서 식립 시 측정값보다 증가하여 만족할만한 안정도를 보였 으며 두 그룹간 유의성 있는 차이는 없었다 $(P>0.05)$. 술 후 48 주에 측정한 임플란트 변연골 소실량은 실험군, 대 조군 모두에서 미미한 것으로 측정되었고 그룹 간에 유 의한 차이는 없었다 $(P>0.05)$. 임플란트 변연골 소실량 은 장기 임플란트 안정성과 생존률에 영향을 주는 중요 한 요인으로, 길이가 짧은 임플란트의 경우 골유합된 고 정체의 길이가 짧으므로 변연골 소실량에 더욱 주의를 기울여야 한다. ${ }^{15}$ 기존 연구들에 의하면 임플란트 식립 후 1년 동안에 임플란트 변연골 흡수가 가장 많이 발생한 다 ${ }^{16,17}$ 고 하였고, 성공적인 임플란트의 변연골 소실량의 기준은 부하 후 1 년간 $1.5 \mathrm{~mm} / \mathrm{yr}$ 이하, 그 이후로는 0.2 $\mathrm{mm} / \mathrm{yr}$ 로 제안하고 있다. ${ }^{18}$ 본 연구에서는 대조군, 실험 군 모두에서 1 년의 관찰기간 동안 $0.1 \mathrm{~mm}$ 이하의 미미한 골흡수가 관찰되어 임플란트의 긍정적인 예후를 예상 가 능하게 한다.

짧은 길이의 임플란트의 사용이 증가하면서 역학적으 로 불리할 수 있는 치관-임플란트 비율에 관심이 커졌고 자연치에서의 치관-치근 비율과 같은 개념으로 치관-임 플란트 비율과 임플란트 성공률 간의 관계를 밝히려는 많은 연구가 이루어졌다. 일반적으로 치관-임플란트 비 율이 높아지면 지렛대 효과로 과부하가 야기되고 nonaxial 부하가 생겨 임플란트에 좋지 않은 영향을 주는 것 으로 알려져 있다. 몇몇의 한계요소분석을 이용한 생역 학적 논문에서는 치관-임플란트 비율이 증가하면 임플란 트 주변골에 높은 스트레스를 야기하고 이는 임플란트 변연골 흡수를 야기할 수 있다고 보고하였다. ${ }^{19,20} \mathrm{Cinar}$ 와 Imirzalioglu $^{21}$ 의 보고에서도 치관-임플란트 비율이 2배 증가할 경우 임플란트 주변 von Mises stresses가 47\% 증가하였다고 하였다. 또한 임상연구들에서도 치관-임플 란트 비율의 증가가 변연골 소실을 증가시킨다는 보고들 이 있다. Malchiodi 등른 36 개월간 259개의 길이가 짧 은 임플란트들을 평가한 결과 치관-임플란트 비율이 2 이상인 경우 변연골 소실량이 증가하였다고 보고하였다. Hingsammer 등 ${ }^{23}$ 은 $6.5 \mathrm{~mm}$ 길이의 74 개의 임플란트를 
관찰한 결과 골흡수량과 치관-임플란트 비율은 강한 상 관관계를 보였으며 치관-임플란트 비율이 1.7 을 넘지 않 아야 조기 골흡수가 증가하지 않는다고 보고하였다.

그러나 위의 연구들과 달리 본 연구에서는 치관-임플 란트 비율과 임플란트 안정성 및 변연골 소실량 간에 유 의성 있는 상관관계가 관찰되지 않았다. 본 연구에서의 치관-임플란트 비율은 최소 0.64 에서 최대 1.89 사이 범 위였으며 대조군과 실험군의 평균 치관-임플란트 비율은 유의하게 차이를 나타냈으나 두 그룹간 안정성 및 변연 골 소실량은 유의한 차이가 없었다. 본 논문의 결과는 치 관-임플란트 비율과 임플란트의 임상적 결과와는 상관 관계가 없고 자연치의 치관-치근 비율에 대한 기존 가이 드라인을 임플란트에 그대로 적용하면 안 된다는 다음 연구들의 결과와 일치한다. Blanes ${ }^{24}$ 는 review 논문에서 치관-임플란트 비율은 임플란트 변연골 흡수에 영향을 주 지 않는다고 하였고, Hof 등 ${ }^{25}$ 도 후향적 임상 연구에서 하 중 부하 후 1 년 그리고 그 이상 기간 동안에도 치관-임플 란트 비율은 임플란트 변연골 흡수에 영향을 주는 요인이 아니라고 하였다. Tawil 등 ${ }^{26}$ 은 109 명의 환자에서 262 개 의 짧은 길이의 machined 표면 임플란트를 53 개월 간 관 찰하여 교합면 크기, 치관-임플란트 비율, 교합 패턴, 캔틸 레버와 변연골 소실량과의 관계를 분석해 본 결과 유의한 상관 관계를 발견하지 못하였다. Mangano 등 ${ }^{27}$ 은 다양한 치관-임플란트 비율을 갖는 68 개의 짧은 임플란트를 치 관-임플란트 비율이 2 이상인 그룹과 2 미만인 그룹으로 나누어 5 년 간 관찰한 결과, 성공률 및 부작용에 있어 유 의성 있는 차이를 발견할 수 없었다고 하였다.

생역학적 측면에서, 일반적으로 치관-임플란트 비율이 증가하면 지렛대 작용에 의해 임플란트 주변골에 가해지 는 스트레스가 증가할 것이라 추정할 수 있고 실제로 생 역학적 논문에서 그와 같은 결과를 보고하고 있다. ${ }^{19-21}$ 그 러나 본 논문에서는 임플란트-치관 비율은 ISQ나 변연 골 소실량에 영향을 주지 않았고 이는 불리한 치관-임플 란트 비율로 인한 임플란트에 대한 스트레스의 증가가 임플란트 안정성을 저해하거나 변연골 소실을 야기하는 임계 스트레스를 넘기지 않았다고 추정할 수 있다. 이러 한 결과의 원인으로 임플란트 예후에 중요한 요인인 초 기 안정성을 확보하고 임플란트에 불리한 스트레스를 줄 이기 위한 본 연구의 설계 조건을 들 수 있다. 본 임상연 구에서는 미리 정한 엄격한 기준에 의해 연구대상자를 선별하였으며 CT를 촬영하여 D4 골밀도의 환자는 배제 하였다. 골밀도는 초기 안정성에 영향을 주는 주요 인자
로 알려져 있으며 이와 관련하여 Lai 등 ${ }^{28}$ 은 104 개의 SLA (sandblasted, large-grit, acid-etched) 임플란트 대상으로 관찰한 결과 골밀도 D1에서의 임플란트가 D4에 비해 높 은 ISQ 값을 나타냈다고 하였고, Turkyilmaz 등 ${ }^{29}$ 도 골밀 도와 ISQ 값 간에는 강한 상관관계가 존재한다고 하였다.

또한 본 실험에서는 식립 시 $35-45 \mathrm{Ncm}$ 의 식립토크 및 65이상의 ISQ값을 나타낸 초기 안정성이 충분하다고 판단된 임플란트만을 실험 대상에 포함시켰다. Östman 등 $^{30}$ 은 임플란트의 즉시 부하를 위한 기준에 ISQ 값을 포 함시켜야 하며 ISQ 65이상을 즉시 부하를 위한 기준으 로 제시하였다. 식립토크 또한 초기 안정성을 확인하는 중요한 수단으로 알려져 있으며 ${ }^{31} 25-45 \mathrm{Ncm}$ 의 식립 토크를 확보한다면 부하 시 발생할 수 있는 미세 동요를 방지할 수 있다고 하였다. 이러한 보고들에 기반하여 본 연구에서는 좀더 보수적으로 $35-45 \mathrm{Ncm}$ 식립토크를 확보하려 하였으며 골밀도가 낮은 경우 수술 시 under drilling을 시행하였다. 임플란트 식립 시 표준 drilling과 정 전체를 따르지 않고 under drilling 시 초기 안정성을 증가시킬 수 있다고 알려져 있다. ${ }^{32}$

본 연구에서 사용된 임플란트 고정체는 SLA 표면으로 기존 많은 연구들에서 sandblasting 과 acid etching 처리 를 통해 임플란트 표면의 거칠기와 세포 반응 속도를 증 가시킬 수 있다고 증명되고 있으며, ${ }^{33-35}$ 최근 가장 신뢰할 만하고 널리 사용되는 임플란트 표면처리방법 중 하나 이다. 임플란트의 표면 뿐 아니라 디자인도 초기 안정성 을 확보하는데 중요한 요인인데 본 연구에 사용된 임플 란트는 self-tapping taper 형태로 taper 형태의 임플란트 는 골밀도가 낮은 경우 피질골에 응축력을 가할 수 있고 스트레스를 분산시킬 수 있는 것으로 알려져 있다. ${ }^{36-38}$ 또 한 CMI IS-III active 임플란트에는 깊은 buttress형태의 thread가 디자인되어 있는데 이와 같은 형태는 기계적인 유지력을 증가시킬 수 있어 초기 안정성 확보에 유리하 다. ${ }^{39-41}$

본 연구에서는 길이 $6.6 \mathrm{~mm}, 7.3 \mathrm{~mm}, 8.5 \mathrm{~mm}$ 길이의 임플란트에 대해서는 표준 길이 $10 \mathrm{~mm}$ 임플란트의 직경 $5.0 \mathrm{~mm}$ 보다 두꺼운 직경 $5.5 \mathrm{~mm}$ 를 사용하였다. 직경이 다른 임플란트의 결과를 비교하는 것은 엄밀한 의미에서 부적절하고 본 논문의 한계라고 볼 수 있으나, 실제 환자 들을 대상으로 하는 임상시험임을 감안하여 짧은 임플 란트의 부족한 골-임플란트 접촉 면적을 보상하기 위해 보수적으로 실험을 설계하였다. 넓은 직경의 임플란트는 골량이나 골밀도가 좋지 않거나 표준 직경 임플란트가 
실패한 경우 대안으로 사용하여 왔다. ${ }^{42,43}$ Horwitz 등 ${ }^{44}$ 은 임플란트 길이, 직경과 ISQ값의 관계를 밝히는 논문에서 임플란트 길이와 ISQ는 상관관계가 없었으며 직경이 큰 임플란트에서 더 높은 ISQ값이 나타났다고 하였다. 유 한요소분석 방법을 사용한 논문들에서도 임플란트와 골 계면에 작용하는 스트레스를 분산시키는 데 임플란트 길 이의 영향은 크지 않았고, ${ }^{20,45,46}$ 초기 안정성은 임플란트 길이보다 직경에 의해 더 많이 영향을 받는다고 보고하 였다. ${ }^{47}$ 이 같은 보고들을 고려할 때, 넓은 직경을 사용한 것은 짧은 임플란트들이 상대적으로 불리한 치관-임플란 트 비율에도 불구하고 안정적인 결과를 나타내는데 일조 할 수 있었다고 추측할 수 있으며 실제 임상에서의 응용 도 기대할 수 있다.

한편, 임플란트가 적절하지 못한 위치와 방향으로 식 립될 경우, 부적절한 방향의 교합력이 가해지게되고 이로 인해 임플란트 주변골에 스트레스가 가해지고 임플란트 주변골 흡수를 야기 할 수 있다. ${ }^{48-50}$ 본 연구에서는 CT와 디지털 모형상에서 보철적 측면을 고려한 임플란트 식립 위치 및 방향을 설계하여 수술 가이드를 제작하여 최대 한 정확한 위치에 식립하였고 이는 임플란트에 부적절한 교합력을 최소화하여 본 연구의 성공적인 결과까지 이어 질 수 있었다고 생각된다.

\section{결론}

본 임상시험 결과, 초기 안정성이 확보된 조건에서, 임 플란트 길이 및 치관-임플란트 비율은 임플란트의 안정 성과 임플란트 변연골 소실량에 영향을 주지 않았고, 10 $\mathrm{mm}$ 이하의 짧은 길이의 임플란트는 표준길이의 임플란 트와 차이 없는 성공적인 결과를 나타내었다. 이에 본 연 구의 한계 내에서, 짧은 길이의 임플란트는 골높이가 부 족한 경우 효율적인 대안이 될 수 있을 것이라 제안할 수 있다. 이를 뒷받침하기 위해서는 더 많은 환자 수와 긴 기 간의 관찰이 동반된 추가적인 연구가 필요할 것이다.

\section{Acknowledgements}

This research was supported by a grant of the Korea Health Technology R\&D Project through the Korea Health Industry Development Institute (KHIDI), funded by the Ministry of Health \& Welfare, Republic of Korea (grant number: HI16C1173).

\section{References}

1. Urban IA, Jovanovic SA, Lozada JL. Vertical ridge augmentation using guided bone regeneration (GBR) in three clinical scenarios prior to implant placement: a retrospective study of 35 patients 12 to 72 months after loading. Int J Oral Maxillofac Implants 2009;24:502-10.

2. Bahat $\mathrm{O}$. Brånemark system implants in the posterior maxilla: clinical study of 660 implants followed for 5 to 12 years. Int J Oral Maxillofac Implants 2000;15:646-53.

3. Herrmann I, Lekholm U, Holm S, Kultje C. Evaluation of patient and implant characteristics as potential prognostic factors for oral implant failures. Int J Oral Maxillofac Implants 2005;20:220-30.

4. Naert I, Koutsikakis G, Duyck J, Quirynen M, Jacobs R, van Steenberghe D. Biologic outcome of implant-supported restorations in the treatment of partial edentulism. Part 1: a longitudinal clinical evaluation. Clin Oral Implants Res 2002;13:381-9.

5. Kotsovilis S, Fourmousis I, Karoussis IK, Bamia C. A systematic review and meta-analysis on the effect of implant length on the survival of rough-surface dental implants. J Periodontol 2009;80:1700-18.

6. Mangano FG, Shibli JA, Sammons RL, Iaculli F, Piattelli A, Mangano C. Short (8-mm) locking-taper implants supporting single crowns in posterior region: a prospective clinical study with 1-to 10-years of followup. Clin Oral Implants Res 2014;25:933-40.

7. Rossi F, Botticelli D, Cesaretti G, De Santis E, Storelli S, Lang NP. Use of short implants $(6 \mathrm{~mm})$ in a single-tooth replacement: a 5-year follow-up prospective randomized controlled multicenter clinical study. Clin Oral Implants Res 2016;27:458-64.

8. Esposito M, Cannizzaro G, Soardi E, Pellegrino G, Pistilli R, Felice P. A 3-year post-loading report of a randomised controlled trial on the rehabilitation of posterior atrophic mandibles: short implants or longer implants in vertically augmented bone? Eur J Oral Implantol 2011;4:301-11.

9. Romeo E, Bivio A, Mosca D, Scanferla M, Ghisolfi $\mathrm{M}$, Storelli S. The use of short dental implants in clinical practice: literature review. Minerva Stomatol 2010;59:23-31. 
10. Telleman G, Raghoebar GM, Vissink A, den Hartog L, Huddleston Slater JJ, Meijer HJ. A systematic review of the prognosis of short $(<10 \mathrm{~mm})$ dental implants placed in the partially edentulous patient. J Clin Periodontol 2011;38:667-76.

11. Grossmann Y, Sadan A. The prosthodontic concept of crown-to-root ratio: a review of the literature. J Prosthet Dent 2005;93:559-62.

12. Jung RE, Pjetursson BE, Glauser R, Zembic A, Zwahlen M, Lang NP. A systematic review of the 5 -year survival and complication rates of implantsupported single crowns. Clin Oral Implants Res 2008;19:119-30.

13. Rosenstiel SF, Land MF, Fujimoto J. Contemporary Fixed Prosthodontics. 4th ed. St. Louis; Elsevier; 2006. p. 42-81.

14. Schillingburg HT, Hobo S, Whitsett LD, Jacobi R, Brackett SE. Fundamentals of fixed prosthodontics. 3rd ed. Chicago; Quintessence; 1997. p. 85-103.

15. Pommer B, Heuberer S, Nahler L, Watzek G. How much bone loss can be prevented by alveolar ridge preservation? Systematic literature review and meta-analysis. ImplantNewsPerio 2012;9:795-9.

16. Simons WF, De Smit M, Duyck J, Coucke W, Quirynen M. The proportion of cancellous bone as predictive factor for early marginal bone loss around implants in the posterior part of the mandible. Clin Oral Implants Res 2015;26:1051-9.

17. Weber HP, Crohin CC, Fiorellini JP. A 5-year prospective clinical and radiographic study of nonsubmerged dental implants. Clin Oral Implants Res 2000;11:144-53.

18. Albrektsson T, Zarb G, Worthington P, Eriksson AR. The long-term efficacy of currently used dental implants: a review and proposed criteria of success. Int J Oral Maxillofac Implants 1986;1:11-25.

19. Bulaqi HA, Mousavi Mashhadi M, Safari H, Samandari MM, Geramipanah F. Effect of increased crown height on stress distribution in short dental implant components and their surrounding bone: A finite element analysis. J Prosthet Dent 2015;113:548-57.

20. Toniollo MB, Macedo AP, Rodrigues RC, Ribeiro RF, Mattos Mda G. Three-dimensional finite element analysis of the stress distribution on morse taper implants surface. J Prosthodont Res 2013;57:206-12.

21. Cinar D, Imirzalioglu P. The Effect of Three Different Crown Heights and Two Different Bone Types on Implants Placed in the Posterior Maxilla: Three-Dimensional Finite Element Analysis. Int J Oral Maxillofac Implants 2016;31:e1-e10.

22. Malchiodi L, Cucchi A, Ghensi P, Consonni D, Nocini PF. Influence of crown-implant ratio on implant success rates and crestal bone levels: a 36-month follow-up prospective study. Clin Oral Implants Res 2014;25:240-51.

23. Hingsammer L, Watzek G, Pommer B. The influence of crown-to-implant ratio on marginal bone levels around splinted short dental implants: A radiological and clincial short term analysis. Clin Implant Dent Relat Res 2017;19:1090-8.

24. Blanes RJ. To what extent does the crown-implant ratio affect the survival and complications of implant-supported reconstructions? A systematic review. Clin Oral Implants Res 2009;20 Suppl 4:67-72.

25. Hof M, Pommer B, Zukic N, Vasak C, Lorenzoni $\mathrm{M}$, Zechner W. Influence of prosthetic parameters on peri-implant bone resorption in the first year of loading: a multi-factorial analysis. Clin Implant Dent Relat Res 2015;17 Suppl 1:e183-91.

26. Tawil G, Aboujaoude N, Younan R. Influence of prosthetic parameters on the survival and complication rates of short implants. Int J Oral Maxillofac Implants 2006;21:275-82.

27. Mangano F, Frezzato I, Frezzato A, Veronesi G, Mortellaro C, Mangano C. The Effect of Crownto-Implant Ratio on the Clinical Performance of Extra-Short Locking-Taper Implants. J Craniofac Surg 2016;27:675-81.

28. Lai HC, Zhuang LF, Zhang ZY. Stability of implants placed in different bone types. Zhonghua Kou Qiang Yi Xue Za Zhi 2007:42:292-3.

29. Turkyilmaz I, Sennerby L, McGlumphy EA, Tözüm TF. Biomechanical aspects of primary implant stability: a human cadaver study. Clin Implant Dent Relat Res 2009;11:113-9.

30. Östman PO, Hellman M, Wendelhag I, Sennerby L. Resonance frequency analysis measurements of implants at placement surgery. Int J Prosthodont 
2006;19:77-83.

31. Robling AG, Turner CH. Mechanical Signaling for Bone Modeling and Remodeling. Crit Rev Eukaryot Gene Expr 2009;19:319-38.

32. Norton MR. The influence of insertion torque on the survival of immediately placed and restored single-tooth implants. Int J Oral Maxillofac Implants 2011;26:1333-43.

33. Bornstein MM, Valderrama P, Jones AA, Wilson TG, Seibl R, Cochran DL. Bone apposition around two different sandblasted and acid-etched titanium implant surfaces: a histomorphometric study in canine mandibles. Clin Oral Implants Res 2008;19:233-41.

34. Buser D, Broggini N, Wieland M, Schenk R, Denzer A, Cochran D, Hoffmann B, Lussi A, Steinemann SG. Enhanced bone apposition to a chemically modified SLA titanium surface. J Dent Res 2004;83:529-33.

35. Schwarz F, Herten M, Sager M, Wieland M, Dard M, Becker J. Histological and immunohistochemical analysis of initial and early osseous integration at chemically modified and conventional SLA ${ }^{\circledR}$ titanium implants: preliminary results of a pilot study in dogs. Clin Oral Implants Res 2007;18:481-8.

36. Klokkevold PR, Nishimura RD, Adachi M, Caputo A. Osseointegration enhanced by chemical etching of the titanium surface. A torque removal study in the rabbit. Clin Oral Implants Res 1997;8:442-7.

37. Piattelli A, Manzon L, Scarano A, Paolantonio M, Piattelli M. Histologic and histomorphometric analysis of the bone response to machined and sandblasted titanium implants: an experimental study in rabbits. Int J Oral Maxillofac Implants 1998;13:805-10.

38. Yeo IS, Han JS, Yang JH. Biomechanical and histomorphometric study of dental implants with different surface characteristics. J Biomed Mater Res B Appl Biomater 2008;87:303-11.

39. Kim JH, Yang JY, Kim YK, Heo YK, Yeo IS. Retrospective results of implants for partially edentulous posterior jaws according to time points of early loading. Int J Oral Maxillofac Implants 2013;28: 1293-9.

40. Kumar ABT, Khalia N, Gayathri GV, Kumar BHD, Mehta DS. Peri-implant crestal bone preservation:
Where do we stand? Int J Oral Implantol Clin Res 2013;4:72-7.

41. Ryu HS, Namgung C, Lee JH, Lim YJ. The influence of thread geometry on implant osseointegration under immediate loading: a literature review. J Adv Prosthodont 2014;6:547-54.

42. Langer B, Langer L, Herrmann I, Jorneus L. The wide fixture: a solution for special bone situations and a rescue for the compromised implant. Part 1. Int J Oral Maxillofac Implants 1993;8:400-8.

43. Renouard F, Arnoux JP, Sarment DP. Five-mmdiameter implants without a smooth surface collar: report on 98 consecutive placements. Int J Oral Maxillofac Implants 1999;14:101-7.

44. Horwitz J, Zuabi O, Peled M. Resonance frequency analysis in immediate loading of dental implants. Refuat Hapeh Vehashinayim (1993) 2003;20:80-8, 104.

45. Anitua E, Tapia R, Luzuriaga F, Orive G. Influence of implant length, diameter, and geometry on stress distribution: a finite element analysis. Int J Periodontics Restorative Dent 2010;30:89-95.

46. Baggi L, Di Girolamo M, Vairo G, Sannino G. Comparative Evaluation of Osseointegrated Dental Implants Based on Platform-Switching Concept: Influence of Diameter, Length, Thread Shape, and In-Bone Positioning Depth on Stress-Based Performance. Comput Math Methods Med 2013;2013: 250929.

47. Simunek A, Strnad J, Kopecka D, Brazda T, Pilathadka S, Chauhan R, Slezak R, Capek L. Changes in stability after healing of immediately loaded dental implants. Int J Oral Maxillofac Implants 2010; 25:1085-92.

48. Dominiak M, Gedrange T. New perspectives in the diagnostic of gingival recession. Adv Clin Exp Med 2014;23:857-63.

49. Yazicioglu D, Bayram B, Oguz Y, Cinar D, Uckan S. Stress Distribution on Short Implants at Maxillary Posterior Alveolar Bone Model with Different Bone-to-Implant Contact Ratio: Finite Element Analysis. J Oral Implantol 2016;42:26-33.

50. Zietek M, Gedrange T, Mikulewicz M. Long term evaluation of biomaterial application in surgical treatment of periodontosis. J Physiol Pharmacol 2008;59 Suppl 5:81-6. 


\section{하악 구치 단일임플란트 수복에서 임플란트 길이에 따른 치관-임플란트 비율이 임플란트안정성 및 변연골소실에 주는 영향}

\section{백연화 ${ }^{1}$, 김봉주 $^{2}$, 김명주 $^{1}$, 권호범 ${ }^{1}$, 임영준 ${ }^{1 *}$}

${ }^{1}$ 서울대학교 치의학대학원 치과보철학교실

${ }^{2}$ 서울대학교 치과병원 치의생명과학연구원

목적: 이 연구의 목적은 임플란트의 길이 및 치관-임플란트 비율(crown-to-implant (C/I) ratio)이 임플란트의 안정성과 임플란트 변연골 소실량(MBL)에 영향을 주는지 알아보기 위함이다.

연구 재료 및 방법: 연구대상자로 하악 구치부에 단일치를 상실한 46명의 환자를 선별하였다. 대조군에는 총 19 개의 직 경 $5.0 \mathrm{~mm}$, 길이 $10 \mathrm{~mm}$ 의 임플란트(CMI IS-III active ${ }^{\circledR}$ long implant)를 식립하였고, 실험군에는 직경 $5.5 \mathrm{~mm}$, 길이 6.6, 7.3, $8.5 \mathrm{~mm}$ 의 임플란트 총 27개(CMI IS-III active ${ }^{\circledR}$ short implant)를 식립하였다. 각각의 임플란트는 디지털 방식으로 술 전 제작한 수술가이드를 사용하여 식립하였고 임시보철물을 장착하여 즉시부하를 시행하였다. 술 후 3개월에 CAD$\mathrm{CAM}$ 방식으로 제작한 지르코니아 크라운으로 최종 수복하였다. 술 후 48주에 ISQ 값과 변연골 소실량을 측정하여 치 관-임플란트 비율과 ISQ 및 변연골 소실량 간의 상관관계를 비교하였다.

결과: 두 그룹 모두 안정도 및 변연골 소실량 면에서 성공적인 결과를 나타내었다. 술 후 48주에 측정한 두 그룹간 ISQ와 변연골 소실량 값은 통계적으로 유의미한 차이가 없었다 $(P>0.05)$. 치관-임플란트 비율과 안정성 및 치관-임플란트 비 율과 변연골 소실량 간에 어떤 상관관계도 관찰되지 않았다 $(P>0.05)$.

결론: 두 그룹의 하악 단일 임플란트에서 치관-임플란트 비율은 안정성 및 변연골 소실량에 영향을 주지 않는 것으로 나 타났다. 골높이가 부족한 하악에서 단일 임플란트 수복 시, 짧은 임플란트는 상대적으로 높은 치관-임플란트 비율에도 불구하고 제한된 조건 하에서 적절한 대안이 될 수 있다.

(구강회복응용과학지 2018;34(4):280-9)

주요어: 치과임플란트; 짧은 치과임플란트; 즉시부하; 초기안정성; 임플란트 변연골소실; 치관-임플란트 비율(crown-toimplant ratio)

*교신저자: 임영준

(03080)서울시 종로구 대학로 101 서울대학교 치의학대학원 치과보철학교실

Tel: 02-2072-2940 | Fax: 02-2072-3860 | E-mail: limdds@snu. ac. kr

접수일: 2018년 9월 7일 | 수정일: 2018년 9월 28일 | 채택일: 2018년 10월 10일 